\title{
Restorative Transformation after Lockdown: Freedom and Ubuntu in Civic Education
}

\section{Gugu Ndlazi}

University of Fort Hare

gugu.ndlazi58@gmail.com

\author{
Christopher Allsobrook \\ https://orcid.org/0000-0001-7701-0811 \\ University of Fort Hare \\ callsobrook@ufh.ac.za
}

\begin{abstract}
We contend that lockdown restrictions to prevent the spread of Covid-19 in South Africa have exposed deep divisions between citizens and the state, due in part to the neglect of citizenship education and to the neglect of our historical citizenship heritage. We propose in this paper two sources of appropriate normative guidelines, rooted in our common, collective history and ethics, which we ought to promote among citizens to reunite our people. We argue that citizenship education ought not only to be promoted actively in schools but that it must be reformed on the basis of two sets of foundational principles: a) Ubuntu; and b) the Freedom Charter. These encourage integration between citizens and subjects, and between citizens and the state; not to impose false universality from above, nor incoherent heteronomy from below, but to regulate these with cultural and historical continuity in transformation.
\end{abstract}

Keywords: citizenship education; Covid-19; South Africa; political theory; ethics; citizenship; apartheid

From a South African perspective, at least two exceptional local features of the 2020 pandemic stand out from its global effects: 1) Much to everyone's surprise, Covid-19 spared us from a high death rate, as compared to many other countries; and 2) The poor bore the brunt of harm, both from the disease and from the effects of regulations imposed to curb its spread. Regarding the death rate, one may venture to suggest, at least part of the reason is that the most vulnerable segments of the population, as threatened by the virus abroad, are already dead. Since wealthy South Africans are protected by socially distancing apartheid geography, they benefit from state restrictions that prevented the disease from spreading among citizens in suburbs (if not through the long queues of closely crowded relief grant recipients around the country).

In effect, our government took the well-informed decision (in contrast with America and Brazil) to follow world-standard medical guidance, to impose severe restrictions on

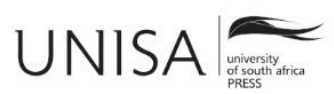




\section{Ndlazi, Allsobrook}

our shaky economy, but, effectively, to protect the health of the vulnerable middle classes and elderly (incidentally those who, by and large, most benefited from apartheid). This perversity follows from a long-running disconnect between citizen and subject in South Africa-a consequence of the constitutive condition of our colonial state, which by design imposes its laws on black subjects and reserves rights for (employed, registered, formerly only white resident) citizens. Once determined by colonials' moral principles of Christian humanism, and now grounded in liberal democratic constitutional best practice, in each case, the law knows better than people.

Having fought for liberation from the colonial state, we have not yet integrated the law of the land with the ways of the nation. The state mistreats subjects, men mistreat women, African citizenship is ceded to narrow nationalism; and cadres treat relief funds as a private pot. Such local features of the pandemic as authoritarianism in enforcement, corruption in consumption of relief funds, and widespread indifference to the law in sales of contraband, as well as the effective protection of citizens at the expense of subjects, all support our claim that a shared sense of citizenship, which reflects the history of our struggle for freedom and reconciliation, has been sorely neglected in our efforts at decolonisation. Decolonisation is often conceived as a radical revolution, but the painstaking process of restorative transformation calls for careful integration of the recognised norms of excluded African subjects, on the one hand, with the formal, Western juristic principles that govern the country.

The stark division in effects of the pandemic for different classes of citizens shows that our dualistic citizenship has been neglected in South Africa's decolonisation, despite its long critique, for instance, by Mahmoud Mamdani in Citizen and Subject and Thabo Mbeki, in his tale of "Two Nations." We are divided by race, class, wealth and income, which afford security of persons, property and land tenure rights, and access to functional health care, education, transport, legal representation, and so forth. We have little sense of ourselves as common citizens. We are not in active solidarity. We are a land of greed and waste in selfish wealth. Citizenship cannot simply be legislated into effect by an ideal constitutional compromise reached in the 1990s between Roelf Meyer, Cyril Ramaphosa and friends. The universalistic conceptions of citizenship in our constitution are not rooted in widely accepted vernacular.

Here we outline two sources of normative guidelines for unified citizenship in our collective history, which, we suggest, we ought to promote among citizens to help reunite our people. Make no mistake, we have reached a serious crisis in this country, which the bubble of the lockdown and pandemic emergency have to some extent obscured. The state is withering away, our economy is stagnant, and conspicuous, wasteful expenditure is out of control. Why do we not see we are robbing our children, that we steal not just from others but from ourselves? South Africans are failing to identify with one another as fellow citizens. We see the state and our laws as belonging to someone else, and to be exploited. Though the reasons behind this regression go back to a long history of exploitation, we are still not taught otherwise. 
Our curriculum in citizenship education is currently based on generic, Western accounts of citizenship, which are not grounded in our accepted ethical norms or struggles for freedom. We argue that citizenship education should not just be promoted actively in schools but that it must be reformed, on the basis of two sets of widely recognised foundational principles: a) Ubuntu; and b) the Freedom Charter. In the wake of the destructive effects of this crisis, as a basis for restorative transformation, these function in fruitful dialectical tension between community and universality to open a way to integrated citizenship; not to impose false universality from above, nor incoherent heteronomy from below, but regulated, according to a principle of continuity in transformation, with reference to recognised norms and precedent judgements widely accepted in local social practices. They redress historically the dualism in South African citizenship directly. Their universality is generated in immanent historical context. We explain how these principles improve on extant models, which to date have neglected the historic roots of South African citizenship in freedom and Ubuntu.

\section{Contested Normative Ground for Decolonised South African Citizenship Education}

The South African National Curriculum (2007) sets out the intention to cultivate the full potential of every learner, as a confident, independent, literate, numerate lifelong citizen, with the ability to participate actively in society with criticism and compassion (Joubert, Phatudi, and Moen 2014, 3). The curriculum was meant not only to transform South Africa's pedagogy, but also our political culture, from domination, obedience and division to equality, self-discipline and cooperation (Chisholm, as cited by Mattes, Denemark, and Niemi 2012, 4). However, we are plagued with public and corporate corruption as crime and violence escalate. Given our acrimonious history of colonialism and racial discrimination, we must engage in effective reconciliation and nation building beyond slogans. The democratic government and the Department of Education ought to invest in decolonised civic education.

As Shanyanana $(2011,1)$ argues, for democracy to prosper, citizens must be taught democratic behaviour, especially in a country where there have been shifts from nondemocratic to democratic governments. Studies by Mattes et al. $(2012,06)$ in Cape Town high schools, for instance, have shown that education for citizenship can effectively promote a democratic disposition for social cohesion among the youth. But, far from introducing citizenship education, the democratic South Africa is yet to define a suitable approach. The normative roots of citizenship education in living political and cultural values must still be recognised explicitly in the curriculum. Citizenship education cannot impose wishful constitutional ideals on citizens, whose normative basis is not recognised in already widely accepted ethical principles. Citizenship education should focus on the cultivation of norms recognised in customary social practices. Otherwise, masks (or official ideals) worn in public come down in informal spaces. 
We argue here that citizenship education in South Africa must be grounded in the shared life of our people, in common ethical values of democratic equality and Ubuntu, with relevance to the real conditions people face. We contend that citizenship education in South Africa ought to be grounded in political values informed by the mass democratic struggle against colonial domination and injustice and by typically African communitarian ethical norms. We argue that successful democratic citizenship education should articulate and address social challenges in terms of the values of Ubuntu and the Freedom Charter. In other developing countries in Africa, such as Ghana (Adams, Andoh, and Quarshie 2013, 19) and Zimbabwe (Makuvaza and Gatsi 2014; Muropa et al. 2013), there is widespread support in the curriculum for culturally relevant citizenship education as a foundation for sustainable democracies (Joubert et al. 2014; Mattes 2002; Podetti 2004). However, we find in the literature that South Africa has neglected this in their restrictive focus on culturally and historically austere science, technology, engineering and mathematics (STEM) subjects with vocational training.

The post-apartheid democratic government inherited an unevenly educated population divided by race, gender and class. Citizenship education was needed to heal the divisions of apartheid by encouraging unifying conceptions of democracy and citizenship (Asmal and James 2001, 186). However, a report compiled by Hammett and Staeheli $(2009,2)$ indicates that South African learners do not see the relevance of citizenship education in learning orientation. This is because, according to Hammett and Staeheli $(2009,2)$, citizenship education does not do justice to our specific political and cultural circumstances. There is too little local content, as they show in an overview of the life orientation lessons from grade 7 to 10 (The South African National Curriculum 2007), which do not discuss or conceptualise the South African Constitution (The Republic of South Africa 1996), the history and ideology of reconciliation in South Africa or what a democratic state is and what it means. The type of citizenship education we advocate must appeal to values that young scholars recognise, to encourage them to transcend barriers of inequality left behind by apartheid.

The aim of citizenship education is to foster a culture of democratic citizenship that reflects shared norms and lived values evident in the lived experience of customary normative social practices; not artificial, externally imposed routines. Learners who do not see the relevance of citizenship education feel disenfranchised from the political system, disillusioned by ongoing inequalities and disparities (Hammett and Staeheli 2009). The recurring problem with the current conceptual framework of citizenship education is that it promotes abstract ethical ideals that do not speak to the common experiences of South Africans. Prominent citizenship education conceptual frameworks, which dominate the field of citizenship education in South Africa to date, still face such conceptual framework concerns which await reform. The re-rooted cuttings of a generic universal democratic citizenship education conceptual framework have not grown well on our complex, multicultural common ground. As Enslin and Horsthemke $(2004,545)$ have shown, these frameworks of citizenship education have not drawn on local heritage and cultural values that hold special significance for South 
African citizens. Citizenship education lacks relevance, value, and purpose because it does not speak to the common South African experience. The imposition of Western ideologies, and neglect of autochthonous African ethical traditions and history have long had a negative impact on both citizenship and education in general.

According to Mathebula (2009, 7-8), South African educational policy has drawn significantly on McLaughlin's framework of citizenship education (1992). His inclusive, maximal (and culturally minimal) conception of citizenship is evident in Podetti's (2004, 02) writings on the Value Citizens Initiative (VCI) programme, initiated in 2001, in partnership with the Department of Education. McLaughlin (1992) explores some of the philosophical difficulties which follow from the task of trying to offer a thick, culturally substantive notion of education for democratic citizenship in the context of a diverse and pluralistic citizenry. One of the central areas requiring attention by philosophers is to give an account of public civic virtues, which satisfy culturally specific communal demands of citizenship, while still remaining compatible with universal demands of critical rationality, equality and cultural diversity.

On McLaughlin's continuum of democracy and citizenship, citizenship education fits a universal set of criteria, by making room for a continuum from maximalist to minimalist conceptions of democracy, which accommodate a full range of expressions that we find instantiated around the world (McLaughlin 1992). Whilst we acknowledge that some principles in this account, such as critical thinking, can be adapted for citizenship education in South Africa, we urge general caution in adopting entire frameworks informed by Western conceptions, which do not always translate well in our unique political and cultural contexts. What is considered proper and acceptable in the West regarding citizenship does not always accord with common norms here. For instance, there is little emphasis on communal spirit or on social interconnectedness, or evidence of proposals for communitarian ethics in this framework.

On the one hand, McLaughlin's continuum deals almost exclusively with public notions of citizenship, to the neglect of citizenship within the private sphere (Schugurensky and Myers 2003). On the other hand, communal values of social interconnection in the public sphere are applicable to African cultural ways of living in private or familial arrangements, commonly thought to hold greater weight in comparison with European, or American, emphasis on individual rights. Such a cultural distinction is commonly maintained in the writings of influential African philosophers, such as Gyekye (1997) (see further below), Wiredu (1992), and Masolo (2010), where, as Wiredu, for instance, remarks, "The individual is brought up, from the beginning, with a sense of belonging and solidarity with an extensive circle of kith and kin ..." (Wiredu 1992, 198).

Furthermore, McLaughlin's framework does not speak directly to historical and contemporary socio-economic challenges suffered by South Africans. Drawing from Mathebula $(2009,107)$, we argue that the Freedom Charter provides a suitable basis for citizenship since it directly documents the historical demands of South Africans. It is 
well known that the Freedom Charter was the statement of core principles of the South African Congress Alliance, which consisted of the African National Congress and its allies: The South African Indian Congress, the South African Congress of Democrats and the Coloured People's Congress, who claimed it represented the submissions and demands of thousands of diverse citizens from all around the country, collected by devolved committees in townships at rallies and meetings. The Freedom Charter is valuable for citizenship education because it explicitly addresses the objectives of the democratic struggle against apartheid for a united citizenry and it calls attention to the social struggles of the impoverished and the oppressed. We need to contextualise democracy and citizenship as such. Notwithstanding resistance due to Africanists' principled rejection of multi-racialism, nor for all its untidiness (Suttner 2015, 2), the Freedom Charter is still valued by South Africans for its expression of South Africans' vision for liberation. Because the Freedom Charter records local social struggles and offers hope for the future grounded in the South African historical context, it should inform South African citizenship, to restore solidarity, in balance and in harmony with autochthonous African cultural normative imperatives of Ubuntu.

Paula Enslin $(2003,73)$ argues that in order to understand South Africa's challenges, one must understand the transitional history of the country in terms of race, segregation, citizenship and power. Enslin (2003, 73-74) argues that South African citizenship is based on both the participatory vision of the anti-apartheid struggle and on citizens as presented in the Constitution. The author discusses such shifting centres of authority in society, together with tensions between what can be called the "official" conceptualisation of citizenship as equal political rights for all citizens, and a more popular interpretation of democratic access to socio-economic rights. South Africa's emerging conceptions of citizenship have to be understood in the context of the negotiated transition to democracy that was marked by the election of 1994, as well as the period of struggle against apartheid that preceded it. In this 1994-2020 transition period, we see, many of our notions of citizenship are still constituted by apartheid categories.

Enslin $(2003,73)$ claims South Africans have not yet reached a settled conception of inclusive citizenship. The government assumed responsibility for a society systematically fractured across a range of divisions such as race, class, gender, ethnicity and language. Division also cut between rural and urban citizens, and between those with land and without (Enslin 2003, 74). Manala $(2002,1033)$ argues that the transition to democracy brought with it the assumption of a clear conception of equal citizenship, political and social freedom, the prospects for economic development, respect for human rights and the opportunity of giving genuine thought to societal reconstruction. However, the nature of and significance for citizenship after the transition is now less clear than it was in 1994, since citizens are not equipped to deal with post-apartheid challenges in an unequal society (Joubert et al. 2014). Despite "widespread support for education, for democratic citizenship to provide the foundation for sustainable democratic societies," lament Joubert et al., "in South Africa there seems to be no large- 


\section{Ndlazi, Allsobrook}

scale initiative to enhance education for democratic citizenship" $(2014,1)$. This sorely neglects a citizenry long accustomed to restrictive, hierarchical commands from a colonial state expecting obedience and not participation. Children need "to experience the benefits of democracy and education," such as basic services, education, and security, the authors argue "for democratic citizenship to build and sustain a resilient democracy" (Joubert et al. 2014, 1).

While racial divisions are less stark than they were under apartheid, a unifying conception of citizenship has not yet settled in popular consciousness. As former President Thabo Mbeki observed in a well-known speech, South Africa still comprises "Two Nations." He described one of these nations as white, relatively prosperous, with access to a developed economy, physical, educational, communication, and other infrastructures. He described the other nation as black and poor, with the worst affected being women in rural areas, the black rural population in general and the disabled, who live under grossly underdeveloped conditions. Everyone has a right to equality of opportunity, but most citizens, especially blacks, live in conditions which do not support their capacity to exercise the right to equality of opportunity. The transition to democracy brought with it the anticipation of equal citizenship, political and social freedom and opportunities for economic development, but this divide in national identity calls into question the legitimacy of abstract appeals to unified citizenship in South Africa.

McLaughlin (1992) and Johnson and Morris's (2010) approach towards citizenship education is meant to be applied universally. In other words, the approach is intended to apply in every political context, since it emphasises critical thinking and promotes citizenship participation. But these principles are not explicitly related to expressions of communal citizenship with local or regional historical and cultural resonance, evident in the Freedom Charter and in ethical norms of Ubuntu, which are commonly recognised in South African normative practice. An African normative model of society typically emphasises interconnectedness and interdependence of citizenship. One's existence is recognised and acknowledged through belonging in a community, where one's community begins with one's extended family. However, these frameworks reflect more of a Western culture of citizenship than an African model.

\section{The Freedom Charter in South African Citizenship Education}

The Freedom Charter aimed to advance every citizen, declaring: "The people shall govern!" and presenting a maximal conception of democracy and citizenship which South Africa strives to achieve, affirming "collective self-rule, equality and freedom," at odds with race-based and ethnicity-based notions of citizenship by apartheid distinguished non-citizens from citizens (Mathebula 2009, 98). The post-apartheid policy remains torn between "transformative" goals of substantive socio-economic development, which call for special focus on the upliftment of the poor, black majority disadvantaged by apartheid and colonial rule, and "democratic" goals of equal political rights and freedoms for each and every citizen (Enslin 2003, 73). The first requires the 
state to treat citizens differently due to past injustices, with privileges reserved for previously disadvantaged citizens; the second requires everyone to be treated equally. We contend that the principles and values of the Freedom Charter reconcile these conflicting goals. The Freedom Charter, firstly, acknowledges that South Africa is divided by distinct citizenships, evident in people's living conditions; and, second, it insists on collective ownership of national resources for all who live and work here. Whereas high walls around private citizens fail to hold back public insecurity and disease, the political economy of the Freedom Charter promotes a remedy of political and economic foundations for full and equal citizenship in interdependence.

The Freedom Charter is a universal document to the extent that some of its demands are claimed in many parts of the world, but it does not sacrifice local content from the specific process in which it was created, incorporating aspirations of people in conditions particular to South Africa. Issues to be debated around the Freedom Charter are not the same today as they were in 1955 or in the 1980 s, but its historical significance helps South Africans to see democratic citizenship as continually adapting to relevant social settings, in resistance to injustice and oppression. The Freedom Charter is a contested document, open to critical interpretation. As Suttner $(2015,2)$ reminds us, it was contested by the apartheid government, by sections of the left, and by some liberals. The Freedom Charter was not written with precision in preparing a constitution. It was a reaction of ordinary people to oppression. Their experiences were recorded with specific demands. Where a specific form of oppression was experienced, this was listed; what was understood to be a remedy was advanced. Very often both the demand and remedies were particular to conditions prevailing in South Africa (Suttner 2015, 2-3).

In June 1955, to put the ideal of citizen participation into action, the Congress of the People was held in Kliptown, Johannesburg, to draw up a charter for the democratic South Africa of the future. The convention was dubbed the People's Assembly because more than two thousand delegates of all different race groups, Europeans, Indians, coloureds and Africans from various cities, towns, villages, factories, and farms throughout the country participated in this extraordinary gathering. The people's demands were collected, debated and expressed in the Freedom Charter (Mathebula 2009, 97). Equality is the Freedom Charter's keynote. It is sounded in the preamble's call for the building of a democratic state without distinction of colour, race, sex or belief. An identical note is struck in the clauses on government proclaiming the equality of rights for all (Freedom Charter adopted by the ANC 2005):

In the liberated South Africa: All people shall have equal rights to use their own language and to develop their own folk culture; All laws which discriminate on grounds of race, colour or belief shall be repealed; while the preaching and practice of national, race or colour discrimination and contempt shall be a punishable crime (Department of Basic Education: Celebrating the Freedom Charter 1995-2005, 13).

The Freedom Charter's explicit communitarian ethic aligns well with Ubuntu. The Freedom Charter distinguishes two objectives in the struggle for democratic citizenship. 
First is the national democratic struggle for equal rights; second, is the call for the restoration of the national wealth to the people, for workers' rights, work security and equality of all classes of people before the law:

South Africa belongs to all who live in it ... [with] government ... authority ... based on the will of the people ... The people shall govern! ... The rights of the people shall be the same ... to use their own languages ... customs ... The people shall share in the country's wealth! ... the national wealth ... restored to the people ... mineral wealth ... banks and monopoly industry shall be transferred to the ownership of the people as a whole ... all other ... to assist the wellbeing of the people ... The land shall be shared among those who work it ... all shall have the right to occupy land wherever they choose ... free to form trade unions ... the right and duty to work.

Third, the Freedom Charter affirms (and qualifies) the right to education:

The aim of education shall be to teach the youth to love their people and their culture, to honour human brotherhood, liberty and peace; Education shall be free ... High education ... on the basis of merit. (The Freedom Charter. SA History Online. https://www.sahistory.org.za/article/freedom-charter)

The Freedom Charter recognises clear historical linkages between capitalist exploitation and discriminatory inequality in South Africa, calling for the return of the country's national wealth to the people and nationalisation of "mineral wealth beneath the soil." These objectives are compatible with state capitalism, since they emphasise a planned economy, public ownership of the means of production, workers' management and equitable distribution of rewards. The Freedom Charter insists that citizenship extends beyond equal rights to economic opportunities for all.

Mathebula (2009) argues that learners find little relevance in citizenship education which speaks of unity and equality where daily inequalities reinforce a gap between the ideal and reality that learners are quick to notice. This is concerning, given the findings of Hammett and Staeheli $(2009,9)$ that teachers "struggled with how they should talk about class and economic issues without alienating learners." These particular challenges, they continue, "are framed by the wider failure of government to provide a coherent framework through which to move to non-racialism and to talk about inequality in ways that do not alienate and divide the nation" (Hammett and Staeheli 2009, 8). But, if learners cannot discuss a political system, which fails to attend to such basic inequalities and disparities, learners fail to see the relevance of citizenship education, as Mathebula observes. It is essential to admit historical divisions which challenge our ideals, as we see in the demands of the Freedom Charter, with norms of solidarity, as recognised in African ethics of Ubuntu.

The Covid-19 lockdown exacerbated and thereby highlighted basic contradictions between private wealth enjoyed by fully recognised citizens, allowing for better health care and more space in periods of social distancing under lockdown, with crowded 
spaces and relatively poor public healthcare for the rest. Outstanding benefits for privileged citizens put the bulk of the burden on black subjects. The Freedom Charter provides us with a direct reference to requisite socio-economic conditions for a peaceful and healthy society. Incorporating this communitarian socialist approach to material provision is a recommended improvement from generic frameworks of citizenship education which have influenced education policy in South Africa to date, which fail to take account of our socioeconomic and cultural divisions, and, as we explain next, which fail to conceive of democracy in accordance with African social norms.

\section{African Ethics of Ubuntu in South African Citizenship Education}

As Mogobe Ramose $(2003,3814)$ explains, Ubuntu emphasises universal philosophical understandings of human being. The idea conveyed by Ramose is that the logic of Ubuntu is directed towards intersubjective humanness, in communal flow, meaning Ubuntu is always a human-ness and not humanism (Ramose2003, 382). He argues that Ubuntu as a concept and experience is linked epistemologically to umuntu through the faculty of consciousness or self-awareness, which releases the speech of being and pursues its rationality by means of a dialogue of being with being. As such, the interaction of umuntu - as an indivisible being; in oneness and wholeness of being - is always in "dialogue for being with being" (Ramose 2003, 380). The Covid-19 public health crisis brings this communion home, as the virus spreads through social networks, like disinformation on the internet, hacking into our human need to share and engage with one another at the basis of its reproductive logic; testing and tracing our movement in communion, from work to school to parties, churches, taxis, shopping malls and funerals.

Traditional African democracy has its roots in people and their relationships, representing our goals, values, ideas, experiences, and aspirations. The system is nurtured, refined or cultured, and modified to reflect the wishes, desires, and experiences of the people (Shanyanana 2011, 58). Waghid $(2009,71)$ points out that Ubuntu is found in almost all African languages under various names, and it denotes human interdependence through deliberative inquiry, grounded in an awareness of human interdependence. Ubuntu takes place when individuals feel part of a community uniting against conflict; the whole community struggles for collective well-being, while seeking joint amicable solutions (Waghid 2009, 76). Ubuntu encourages the community to deliberate on issues affecting the common good, such as public security and health.

Waghid $(2009,76)$ describes Ubuntu as "human interdependence through deliberative inquiry ... [that] exists in most of the African languages, although not necessarily under the same name." Makgoba (1996) as cited by Enslin and Horsthemke (2004, 547) observes that Ubuntu is a unique virtue of African citizenship to the extent that it emphasises respect for the non-material, spiritual order that exists in us and among us; emphasising one's respect for oneself, for others, and for the environment. Ubuntu accommodates other cultures and it is the invisible force uniting Africans (Makgoba 1996, 130) as cited by Enslin and Horsthemke (2004, 547). Participants who show a 
sense of Ubuntu, that is being compassionate, hospitable, generous and kind, are required to see educational debates on policy development, school governance and pedagogical activities as issues of concern to be addressed by all (Waghid 2009, 76). The promotion of a model of citizenship education which is ingrained in Ubuntu would promote hospitality, solidarity, kindness, and generosity. Democratic debates taking place in citizenship education are improved by an orientation which aligns with Ubuntu to improve on listening skills in communication, to develop an understanding of responsibility as a citizen and to engage with others with compassion and hospitality.

Democratic education grounded in communitarian ethics of Ubuntu appeals to normative values recognised by many, if not all, South Africans. Values of Ubuntu, like those of any other culture, are acquired in society and transmitted from one generation to another by language and common practices (Kamwangamalu 1999, 24-41). As Gyekye (1997) reminds us, traditional African politics exhibited features or elements of democracy, to be adapted for contemporary application. Gyekye (1997) challenges ideas that modernity for African people must be modelled on Western values and institutions. Citizenship education in the ethics of Ubuntu helps young citizens to appreciate their own cultural values, rooted in our history. African customs and traditions of Ubuntu are considered to enable individuals and the community to assist victims of injustice. Gyekye (1997) argues that if African modernity and its challenges and problems are to be endured and addressed in a way that will be meaningful to its people, it must be forged and creatively refined within the "furnace" of deliberations between African intellectual creativity and Africa's multifaceted cultural experience and tradition. Likewise, we should draw on the cultural resources of Ubuntu to forge such citizens of African modernity.

Just as individual identity in the interpersonal ethics of Ubuntu is grounded in intersubjective dynamics, as in the phrase "A person is a person through other people," so, this translates, correspondingly in politics, as "A leader is a leader through his/her people." Citizenship does not just represent people's personal values, experiences, and aspirations but also depends on open public fora for citizens to participate in dialogue on issues of common concern, regardless of their status or level of education. There are noticeable democratic elements in traditional African political kingdoms. According to Shanyanana (2011, 58), the African traditional system represents democracy where the chiefs or kings are chosen by the people. Even when this is done through representatives selected by the masses, elected chiefs or kings have to rule with the consent of the people. Gyekye reinforces his notion of democracy within the African traditional system by citing Sithole's general observation of democracy, namely that:

Those who have lived in Africa know the African people are democratic to the point of inaction. Things are never settled until everyone has had something to say. The traditional African council allows free expression of all shades of opinions. Any man has full right to express his mind on public questions and to carry out any program, required the sanction of the whole clan or tribe. (Gyekye 1997, 118) 
Traditional African town or state councils that have served as instruments of political participation and involvement have not regarded wealth as the basis for membership in councils (Shanyanana 2011, 58). This negotiated discursive process, based on tradition and the wisdom of ancestors and elders regarding prior judgments on relevant cases, is central to African jurisprudence and civic reasoning. This process is carried out with the free expression of consent, opinion, popular will or common interest, consensus and consultation. Participants speak and deliberate by presenting arguments aimed toward a reasonable consensus. Decisions are made in an open and accountable manner, in line with the traditional system of rule and, at the same time, intolerance of misrule is demonstrated by the people as an indication of dissatisfaction with service. In the traditional African system, the political organisation's well-being, success, and survival are matters of concern for everyone; that is, for the public interest and common good or idea of the state as res publica (Gyekye, in Shanyanana 2011, 59). The understanding is that the participatory nature of the democratic practice and the communication structure of African society serve the purpose of democracy by paying close attention to the formulation of towns, district councils and villages, to assure participation of local people in making decisions that affect their lives; they are part of the political process on a daily basis.

We acknowledge the objection of Enslin and Horsthemke $(2004,543)$ that "it remains unclear how characteristically African ways of philosophising are meant to help resolve problems and clarify issues in education for all citizens" (Enslin and Horsthemke 2004, 547). Ramphele $(2001,15)$ expresses a similar viewpoint when she argues: "Ubuntu as a philosophical approach to social relationships must stand alongside other approaches and be judged on the value it can add to better human relations in our complex society. ... The refusal to acknowledge the similarity between Ubuntu and other humanistic philosophical approaches is in part a reflection of the parochialism of South Africans and a refusal to learn from others." However, this does not detract from the value of Ubuntu for citizenship education. Even if Ubuntu is not unique, this does not show that it is inappropriate here. Secondly, the authors argue that Ubuntu restricts moral reasoning to human benefit and does not foster respect for the environment's intrinsic value. But it is just as well for our own sake that we care for our environment. Whether we care for the natural environment so that it can support humans, or out of care for its own well-being, the implications are, either way, that we ought to care for our mother nature. Thirdly, they contend that the claim for an "invisible force uniting Africans worldwide" is betrayed by genocide, dictatorships, corruption and sexism in the African continent. But the same could be said for most ethics if we commit such an is-ought fallacy. The world sees corrupt Zoroastrians, libertarians and nuns, who have not done as they ought. No African ethical premise would support such hardships in Africa to which the authors refer.

Letseka (2012b, 42-43) makes a case for the uniqueness of Ubuntu in the educational discourse, in that Ubuntu is concerned with relationships built for their own sake and not in support of care. Enslin $(2003,72)$ argues that "care" is a Westerner's idea of 
Ubuntu. South African democracy is marked by extreme social inequalities between the material conditions of the elite and millions who are illiterate and poor. Economic injustice demands more than an ethic of care. Ake $(1993,241)$ argues that for citizenship education to be relevant and sustainable in African democracies, it must de-emphasise abstract political rights and stress concrete economic rights, since the demand for democracy in Africa draws much of its impetus from prevailing economic conditions. Drawing on Ake's argument, in citizenship education in South Africa it is important to acknowledge not only abstract political rights but also substantive economic rights in fighting inequality and socio-economic challenges.

Teaching is aided by drawing on learners' understanding, values and concepts, in dialogical or hermeneutic pedagogy, so we should draw on historically resonant African cultural resources. The Freedom Charter and ethics of Ubuntu are widely recognised by South African citizens, and they both align well with functions of citizenship education. Furthermore, the material concerns of the Freedom Charter align well with communitarian ethics of Ubuntu. In promoting cultural tolerance and appreciation of difference through a shared culture, shared resources and shared values, learners learn to identify with one another and to work together toward common goals. Shared culture gives learners a shared historical identity, giving them a feeling that they are a team to which everyone belongs. Ubuntu already enjoys widespread acceptance among all South Africans and the demands of the Freedom Charter have proven a powerful impetus for people to appreciate non-racial ideals, promote multicultural tolerance and appreciate differences.

\section{Citizenship Education through Ubuntu and the Freedom Charter}

In our account of citizenship education, we not only incorporate values of Ubuntu and the Freedom Charter, such as generosity, companionship, friendship, caring, solidarity and togetherness, but also build on work by authors such as Gyekye (1997), Venter (2004), Letseka (2012a and 2013), Shanyanana (2011), and Makuvaza and Hapanyengwi-Chemhuru (2014) who emphasise the need for the values of Ubuntu in primary and higher education, since these values capture what it means to be an African and to capture their lived experiences of what they understand to be an African way of life. What kind of education forges a sense of unity that includes marginalised people in a practical sense? Cheikh Anta Diop, in an edited paper by Teresa Washington (2016), argues that unified citizenship depends on a shared history, culture, language and values. Since South Africa lacks these bonds to assist the transition from apartheid to democratic unity, citizenship education is needed to instil in citizens a shared historical project, which gives them a feeling that they are working together. We must consciously fashion an African education system that will repair the colossal damage that centuries of conquest, oppression, and more than a century of inferior, Eurocentric education wrought on the African psyche.

Former President of South Africa, Thabo Mbeki, referring to the historic Freedom Charter, argued that the document has the potential to assist in the reconstruction and 
development of South Africa because it remains the only document which spoke to all South African people, black or white, which forges a concept of equal citizenship, opportunities, and freedom. Likewise, Ubuntu is grounded in the belief that moral value fundamentally inheres not in the individual but in relationships between individuals. This approach to citizenship is based not on individual sovereignty, but on intersubjective community. The ideologies which surrounded the formation of the Freedom Charter encourage all who live in South Africa to identify with each other, ultimately thinking of themselves as members of the same group; to conceive of themselves as a "we" and to engage in joint projects, coordinating their behaviour to realise shared ends, including equality for all, freedom from suffering and inequality and for the doors of education to be opened and accessed by everyone.

Unity is the most prominent value of the Freedom Charter, since this includes shared ideologies, goals, wealth and opportunities. When unity is achieved, society can prioritise relationships based on shared ideologies and common values. Without peace, unity, and cooperation, our heroes' efforts in building this democratic country are undermined. The history of the Freedom Charter reminds us that the formulation of this historic document would not have been successful unless all South Africans, including blacks, Indians, coloured, and whites, had come together in united solidarity and communion, fighting against dehumanisation, discrimination and segregation. The formulation of the Freedom Charter would not have been successful if South Africans were not willing to work in solidarity to create an anti-apartheid document, which calls for full citizenship, freedom, and equality for all. Solidarity is crucial for social cohesion, to strengthen and consolidate democratic citizenship (Olivier de Sardan 1999, 39-40). When people no longer feel a sense of shared identity and national belonging, conflict is exacerbated. Citizenship education must recognise and instil African social norms which maintain our sense of community, where good governance and mutual respect in social relationships means a great deal to people. The values of Ubuntu, such as unity, solidarity, intersubjectivity and teamwork, speak to social norms already maintained in everyday practice to sustain communities in tolerance, trust, respect, through conflict over socio-economic problems.

Our advocated approach to citizenship education differs in many respects from the generic Western conceptualisation of citizenship education we discussed. The values that South African citizenship education ought to promote are grounded in communal norms and values as opposed to individual dignity or universality. Western citizenship education does not place such value on community or extended family. An inclusive, people-centred, community-based and socialist African framework is needed to heal alienation between citizen, subject and state.

Decolonising knowledge is not a simple matter of de-Westernisation, but current frameworks of citizenship education in South Africa are based on a liberal, individualist orientation that does not fully reconcile with communal and socialist foundational values relevant for South African citizenship, which are evident in our history. Four 
primary values of our recommended approach to citizenship education include unity, solidarity, interconnectedness, and friendship. These values are significant, since they express values which spring from the recognition of oneself in collective struggles for freedom. They reflect what Africans understood to be right in their fight for citizenship, against the discrimination of apartheid, which separated people into different types of citizens on the basis of racial or ethnic distinction. These values of citizenship are aligned with recognised African customary norms and common conceptions that bound us together in the mass democratic struggle against apartheid injustice.

Whereas the principal measure to fight Covid-19 is self-isolation, it is noteworthy that communitarian and socialist nations of the East have proved more successful to date in overcoming the virus than the individualistic societies of the wealthier, better resourced, more highly developed West. The correlation is significant, whatever reasons drive it, for its demonstration of the attitude of the state toward its citizens, and of citizens toward one another, with attendant responsibilities to take care for each other. The contrasting attitudes of the Chinese or US state toward citizens are evident in different practical responses to the virus: where the US left citizens to fend for themselves, the former showed urgent, organised care. In the liberal democratic capitalist West, the state is defined negatively, by private rights against it. But in the African ethics of Ubuntu and in our Freedom Charter the state is grounded on collective obligation and public duties. Where authoritarianism is attributed to China's success in curbing its spread, aside from this significant driver, we urge consideration of two significant neglected factors: the civic role of communitarian and socialist ethics of communal solidarity.

For a communitarian African polity, citizenship education ought to foster active, critical and inquiring citizens who seek out of a sense of duty to contribute to the common welfare of all. Our education policy has failed to instil in learners the basic values of effective participation. Alienated South Africans tend to express political grievances with violence and destruction. A generic model of citizenship education has been imported and neglected, since it is not rooted in homegrown struggles to overcome social divisions of race, class and gender.

Mass rejection of "ethnic nationalism" in the 1950s South Africa gave rise to popular notions of democratic citizenship, associated with the Freedom Charter tradition, and also with African values, as represented by PAC and related Azanian groupings. However, the irony of this history of mass democratic struggle, premised on African ethics of Ubuntu, is that citizenship education has not been encouraged after the antiapartheid struggle, as enshrined in the Department of Education's mission statement (2002). Insofar as it is integrated into teaching, citizenship education does not speak to its intended audience. Educational policy developments during the period of "consensus seeking" in the transition from apartheid have exhibited a trend towards a narrowing of the educational policy agenda toward language, science and maths, neglecting the cultural history and ethics of "People's Education for People's Power," rooted in 
African ethics and in our local struggles that embody a shared conception of citizenship for all.

In short, we have argued as follows: 1) Peculiar features of the local pandemic point to a divide between citizens and subjects in this nation, which calls attention to;2) the need to promote and to develop a specific mode of citizenship education distinct from generic models; 3) grounded in widely recognised normative values, i.e., of Ubuntu and the Freedom Charter; 4) evident in our collective historical struggle to reconcile "subjects" with citizens. The generic adopted frameworks that have influenced citizenship education in South African schools to date have not drawn directly on our rich historical and ethical heritage of active citizenship. Ubuntu articulates social interdependence or a deep rootedness in the community, in reverence for human life, dignity, respect, caring, and compassion. The Freedom Charter demands socioeconomic justice, common understanding and mutual recognition, in a country deeply fractured by oppressive apartheid policies and discredited social divisions. Both the Freedom Charter and ethics of Ubuntu call for solidarity and the common good. Decolonised citizenship education is arguably better achieved if we recognise the core values on which this country was built, in terms of freedom, equality, and democracy, to teach learners recognised common norms which have long held together our shared way of life in defiance of colonialism and apartheid.

\section{References}

Adams, F. H., S. Andoh, and A. M. Quarshie. 2013. "Effective Teaching of Citizenship Education in Primary Schools in Ghana." Journal of Education and Practice 4 (10): 1823. International Knowledge Sharing Platform. https://www.iiste.org/Journals/index.php/JEP/article/view/5787/5930.

Ake, C. 1993. "The Unique Case of African Democracy." International Affairs 69 (2): 239244. https://doi.org/10.2307/2621592.

Asmal, K., and W. James. 2001. Education and Democracy in South Africa Today. The MIT Press on behalf of American Academy of Arts and Science.

Department of Education. 2002. National Curriculum Statement (NCS), Policy Handbook for Educators, 46-47.

Department of Basic Education and the African National Congress. 2005. Celebrating the 55th Birthday of the Freedom Charter.

Enslin, P. 2003. "Citizenship Education in Post-Apartheid South Africa." Cambridge Journal of Education 33 (1): 73-83. https://doi.org/10.1080/0305764032000047513.

Enslin, P., and Horsthemke, K. 2004. "Can Ubuntu Provide a Model for Citizenship Education in African Democracies?" Comparative Education 40 (4): 545-558. https://doi.org/10.1080/0305006042000284538. 
Freedom Charter. 2005. SA History Online. Accessed 4 December 2020. https://www.sahistory.org.za/article/freedom-charter.

Gyekye, K. 1997. Tradition and Modernity: Philosophical Reflections on the African Experience. Oxford: Oxford University Press.

Hammett, D., and L. Staeheli. 2009. "Citizenship Education in South Africa: A Report to Schools.” A supplemented post-doctoral fellowship from the University of Witwatersrand.

Johnson, L., and P. Morris. 2010. "Towards a Framework for Critical Citizenship Education.” The Curriculum Journal Vol. 21: 1-30. https://doi.org/10.1080/09585170903560444.

Joubert, I., N. Phatudi, and M. Moen. 2014. Education for Democratic Citizenship Education through a Literacy-based Approach: A Case of South African Township Children. John Wiley and Sons and National Children's Bureau, 421-433. https://doi.org/10.1111/chso.12070.

Kamwangamalu, N. 1999. "Ubuntu in South Africa: A Sociolinguistic Perspective to a PanAfrican Concept.” South-North Cultural and Media Studies 13 (2): 24-41.

Letseka, M. M. 2012a. “An Analysis of Undergraduate Philosophy of Education Students' Perception of African Philosophy." Doctoral dissertation, University of South Africa.

Letseka, M. M. 2012b. "In Defence of Ubuntu." Studies Philosophy Education: An International Journal 31 (1): 47-57. https://doi.org/10.1007/s11217-011-9267-2.

Letseka, M. M. 2013. "Educating for Ubuntu/Botho: Lessons from Basotho Indigenous Education." Open Journal of Philosophy 3 (2): 337-344. https://doi.org/10.4236/ojpp.2013.32051.

Makuvaza, N., and O. Hapanyengwi-Chemhuru. 2014. "Hunhu: In Search of an Indigenous Philosophy for the Zimbabwean Education System.” Journal of Indigenous Social Development 3 (1): 1-15.

Makuvaza, N., and R. Gatsi. 2014. "Early Childhood Development (ECD) and Educated-ness in an Afro-Zimbabwean Context: The Role of Philosophy of hunhu/Ubuntu." International Journal of Social Sciences and Education 4 (2): 368-378.

Manala, M. J. 2002. "Education for Reconstruction: A Post-apartheid Response to the Education Crisis in South Africa." HTS Teologiese Studies/Theological Studies 58 (3): 1032-1055.

Masolo, D. A. 2010. Self and Community in a Changing World. Bloomington and Indianapolis: Indiana University Press.

Mattes, R. B. 2002. “South Africa: Democracy without the people?" Journal of Democracy 13 (1): 23-36. https://doi.org/10.1353/jod.2002.0010. 
Mattes, R. B., D. Denemark, and R. G. Niemi. 2012. "Learning Democracy? Civic Education in South Africa's First Post-apartheid Generation." Presented at the 7th General Conference of the European Consortium for Political Research, 1-43.

Mathebula, P. T. 2009. "Citizenship Education in South Africa: A critique of Post-apartheid Citizenship Education Policy.” Doctoral thesis, University of Witwatersrand.

McLaughlin, T. H. 1992. "Citizenship, Diversity and Education: A Philosophical Perspective." Journal of Moral Education 21 (3): 3-10. https://doi.org/10.1080/0305724920210307.

Muropa, C., L. P. Kusure, D. Makwerere, R. Kasowe, and Z. Muropa. 2013. "Unhu/Ubuntu and Its Relationship with Civics and Citizenship Education." Scholarlink Research Institute Journals 4 (4): 658-661.

Olivier de Sardan, J. P. 1999. “A Moral Economy of Corruption in Africa?” The Journal of Modern African Studies 37 (1): 25-52, Cambridge University Press. https://doi.org/10.1017/S0022278X99002992.

Podetti, C. 2004.” Citizenship Education.” Presented at the Fifth Annual Educational Speaking Conference, 1-6.

Ramose, M. B. 2003. "The Ethics of Ubuntu." In The African Philosophy Reader, 2nd edition, edited by P. H. Coetzee and A. P. J. Roux. London: Routledge, 379-387.

Ramose, M. B. 2004. "In Search of an African Philosophy of Education. ” South African Journal of Higher Education 18 (3): 138-160. https://doi.org/10.4314/sajhe.v18i3.25487.

Ramphele, M. 2001. “Citizenship Challenges for South Africa's young democracy.” Daedalus 130 (1): $1-17$.

Schugurensky, D., and J. P. Myers. 2003. "Citizenship Education: Theory, Research and Practice.” Encounters on Education, Vol. 4: 1-10. https://doi.org/10.24908/eoe-eserse.v4i0.655.

Shanyanana, R. N. 2011. "Education for Democratic Citizenship and Cosmopolitanism: The Case of the Republic of Namibia." Doctoral thesis, Department of Education Policy Studies at Stellenbosch University.

Suttner, R. 2015. “The Freedom Charter @ 60: Rethinking its Democratic Qualities.” Historia 60 (2): 2-9. https://doi.org/10.17159/2309-8392/2015/V60N2A1.

The Republic of South Africa: Constitution. 1996. Pretoria.

The South African National Curriculum: Department of Basic Education. 2007. 


\section{Ndlazi, Allsobrook}

Venter, E. 2004. "The Notion of Ubuntu and Communalism in African Educational Discourse." Studies in Philosophy and Education 23 (2-3): 149-160.

https://doi.org/10.1023/B:SPED.0000024428.29295.03.

Waghid, Y. 2009. Universities and Public Goods: In Defence of Democratic Deliberation, Education in South Africa. A Scholarly Look behind the Scenes. SUN PRESS: South Africa, 71-83.

Washington, T. N. 2016. "The African World in Dialogue: An Appeal to Action!” Book review presented at the Education Dialogue in collaboration with the Department of Basic Education, Sandton.

Wiredu, K. 1992. "Moral Foundations of an African Culture." In Person and Community: Ghanaian Philosophical Studies, edited by K. Wiredu and K. Gyekye. Washington DC: Council for Research in Values and Philosophy, 193-206. 